\title{
An Investigation into Factors Inhibiting the Growth of Women- Owned Businesses: A Case Study of Hand in Hand, South Africa, Johannesburg
}

\author{
Mrs Sibongile Sibanda ${ }^{1}$, Prof. Edmore Mutekwe ${ }^{2}$ \\ ${ }^{1}$ Management College of Southern Africa (MANCOSA) \\ ${ }^{2}$ North-West University, Faculty of Education and Training, South Africa
}

\begin{abstract}
The aim of this mixed method study was to identify factors that influence the growth of women owned businesses. It was a case study of one organisation in the Johannesburg area of South Africa.A sample size of 20 women was purposively selected from the 210 trained women entrepreneurs in the organization's data base. It employed a closed ended-questionnaire and focus group discussion to collect the data. Two focus group discussions were held with the 20 women entrepreneurs and who also completed a questionnaire consisting of closed ended questions on issues considered pertinent to the study. Data were then analysed thematically with the emerging themes being clustered into super ordinate themes that formed the basis of the discussion of findings in the study. The study established that the potential to grow for women's businesses is limited by factors such as the regulatory environment, inaccess to finance, unavailability of working space and lack of adequately packaged business development services. On internal factors influencing business growth the study found out those personal characteristics, values, beliefs and abilities had an influence on the business growth. The study concluded that the external and internal environments have an influence on business growth especially for women. Further to this, it also emerged that the women's lack of entrepreneur capabilities and their poor exposure due to patriarchy influence the way they interpret their business environment and business growth. The study thus recommended stepping up women capacity development programmes targeted at building sound entrepreneurship
\end{abstract}

\section{Introduction}

This mixed methods study sought to identifyfactors that limitthe growth of women owned businesses focussing on one organization in a township area in the Gauteng province of South Africa. Women in disadvantaged communities engage in economic activities out of necessity, mainly driven by lack of employment and poverty (Gauteng Department of Economic Development, 2014:4). Promotion of entrepreneurship is viewed as an integral part of small business development in South Africa resulting in a number of programmes from the private sector, government and non-governmental organisations.Current literature on small enterprises for example Morrison et al (2003:417) focuses on provision of omnibus business development services which are considered to have potential of influencing growth of the small businesses with little attention placed on the role of human capital in influencing business growth. Having worked with small businesses in provision of business related training as well as review of progress reports it is clear that business support efforts such as training, access to finance, access to technology are not on their own sufficient to influence business growth. Progress reports (Hand in Hand 2014) on support to small enterprises have not captured vital information on the entrepreneurial capabilities as they affect business decision making, application of resources as well as interpretation of the operating environment.

Small businesses are considered vital to the country's ability to create jobs of a diversified nature, produce new products, services or technology and enhance overall productivity at the national and global level (Gauteng Department of Economic Development 2014:4) Furthermore, small businesses are being hailed as the engine of economic growth, the incubator of innovation and the solution to decades of persistent unemployment (Morrison et al, 2003:417). Small businesses have however not lived up to the expectationsleading to some scholars questioning whether small businesses per se are entrepreneurial (Hoy 2008:153). Women entrepreneurs operating retail (Spaza) shops in the communities generally do not realise increased levels of trading nor do they create jobs for others. Furthermore,they face severe competition from other players in the market. Literature identifies a number of factors that inhibit the growth of small businesses such as low levels of entrepreneurial spirit to be holding back innovation and business expansion, lack of desire to confront and/or to change factors at work at personal, business and external environment levels (Morrison et al. 2003:418).

According to a World Bank study on the South African Economies (2014), Diepsloot is a township established in 1995at the end of apartheid making it the newest settlement in Johannesburg with a population of 200,000 people. The World Bank study confirmed that the vast majority of the townships self-employed indeed 
are "survivalists.", firms are mostly informal, new and micro-size and that Diepsloot also harbours a rising class of "active entrepreneurs." The active entrepreneurs are by choice profitably running growth-oriented, employment generating businesses with potential of doing so on a large scale. These businesses are found in the processing activities or in construction, welding and furniture making. The World Bank study (2014) further reports that growth oriented entrepreneurs tend to attract more technically skilled entrepreneurs in relation to retail trade businesses. Other businesses documented by the study include small businesses in the services sector that is, hairstyling and beauty salons in particular, as well as child care and a few informalcomputer training schools.

\section{The Research Problem}

The potential to grow for women's businesses is limited by circumstances that need to be explored to establish the reasons why they militate against women's growth in entrepreneurship (Ligthelm, 2008). Literature on the subject cites such factors as the regulatory environment, their inaccessibility to finance, unavailability of working space and lack of adequately packaged business development services. This study thus sought to explore and unmask some of these factors with a view to establishing their exact effects in the process. It appears that other than patriarchy or male domination in society, there is a complex multidimensional set of factors that interfere with women's growth in business development categorised as both internal (the entrepreneur and use of resources in the business) and external factors to do with the economy and the industrial factors(Nevin, 2005). Intervention strategies in women's business development thus need to be focussed at the entrepreneurial and the external factors to effectively support the women entrepreneurs to grow to the next level.It is not clear how a number of factors such as entrepreneurship traits, operating environment, access to markets, access to finance influence the growth of women led businesses. The research thus sought to identify the key factors at work in influencing the women business trajectories, business skills training and other support efforts for striving women entrepreneurs (Nieman, Hough \& Nieuwenhuzen, 2008).

\section{Aim of the Study}

The aim of this study was to identify factors that influencethe growth of women owned businesses among Hand in Hand Southern Africa supported women entrepreneurs in Diepsloot, Johannesburg. The study specifically identified factors that have led to growth of women led businesses and determined the factors that inhibit growth as well as the role of entrepreneurial human capital in influencing business expansion. The results were used to generate suitable recommendations to Hand in Hand Southern Africa's management on the design of business support services for women owned businesses in order to influence business growth. Pursuant to this aim, the research objectives are formulated as detailed below.

\section{Research Objectives}

- To identify the role of the internal and external business environments in facilitating and inhibiting the growth of women owned business enterprises

- To explore the role of entrepreneurial human capital development in influencing women's business expansion

- To establish suitable recommendations to affect the management of Hand in Hand Southern Africa on the elements to include in enterprise support programmes for women entrepreneurs.

\section{Research Questions}

The study was guided by the following research questions;

- What is the contribution of the internal and external business environments in facilitating and or inhibiting growth of small businesses?

- Does entrepreneurial human capital development influence women's business expansion initiatives?

- How can enterprise support programmes be structured to influence women's business growth?

\section{Significance Of The Study}

It is envisaged that upon completion, the findings of this study will go a long way towards contributing practically to the field of women entrepreneurship development not only in Gauteng but also nationally. On the theoretical level, it is hoped that the findings will contribute to an existing body of literature on women entrepreneurship development initiatives in the country and beyond. In terms of policy level contributions, the findings are envisaged to influence policy regarding raising an awareness of gender balance in the approaches in the development of business entrepreneurs. The identification of key factors inhibiting the growth of small businesses is an important step towards developing effective business support programmes and therefore the results of the study would influence the development of sound approaches towards business development initiatives. Given the assumptions of the human capital theory, which maintain that business entrepreneurship 
development skills provide individuals with increases in their cognitive abilities, leading to more productive and efficient potential activity, the findings of this study would certainly go a long way in this regard (Rwigema, Urban \&Venter, 2011:41).

\section{Literature Review}

This section of the study provides a review of the literature related to challenges affecting growth and development of women led small businessesin townships. It is guided by the philosophy that the more a researcher understands trends in the field not necessarily similar but related to her study the more she is able to approach her own study from an informed position (Nieuwenhuis, 2016). Furthermore, according to Wasserman (2014) reviews need to display a competent examination of earlier research and a comprehensive review of recent relevant literature. The literature review is thus conducted in line with the following subheadings as derived from not only the aim and objectives but also research questions of the study:theoretical framework used as the lens for the study, factors that promote or inhibit growth of small businesses, the role of human capital in influencing business growth and role of support services in the growth of small businesses (Calas, Smircich \& Bourne, 2009).

\section{Theoretical Framework}

The study is guided by the human capital theory and the feminist theoryas the lens for viewing the problem of growth of small businesses. The human capital theory maintains that knowledge provides individuals with increases in their cognitive abilities leading to more productive and efficient potential activity (Rwigema et al 2011:42). Human capital theory recognises variables such as skills, knowledge and resources as key distinguishing factors for entrepreneurs. The ability to act entrepreneurial is considered to be related to variables such as education, work experience, entrepreneurial experience, prior knowledge, prior knowledge of customer problems and experiential knowledge (Rwigema et al 2011:42). Entrepreneurial commitment and competence are considered to create entrepreneurial capital which is defined as the net worth of the capability to exploit future opportunities (Bryman \& Bell, 2007). Exploring the behaviour of small business owners in light of the two intention based models: Ajzen's theory of planned behaviour and Shapero's model of entrepreneurial event will shed light on possible intervention strategies in supporting the growth and development of small businesses (Paterson, 2004)

Feminist theory is used to describe a range of theories in relation to women's movement and was first used by Susan Bolotin's 1982. The feminist theory dates back to the $19^{\text {th }}$ century. Literature identifies three waves of the theory influenced by a number of scholars for example Imelda Whelehan and Estelle Freedman (Hutchinson \& Mann 2006:400). During the $19^{\text {th }}$ century wave, feminism focussed on equal contract and property rights as well as ownership of women and their children. The second wave (early 1960s) of feminism focused on the fight for social and cultural inequalities. For example, Friedan believed that women were victims of a false belief system that requires them to find identity and meaning in their lives through their husbands and children by finding their identity in their husbands and children, women lose their identify (Calas, Smircich \& Bourne, 2009:552).

According Peterson (2004:552), feminist argue that there is no single feminist theory. There are rather a wide range of theories linked by their attention to social differentiations. Versions of feminism include radical feminism, liberal feminism and Marxist feminism. Radical feminism is about oppression of women by men where patriarchy is considered hard to eradicate because it is rooted on a belief that women are inferior. Liberal feminism on the other hand argues that there is no difference between men and women hence there should be equal representation in all sectors of the economy. On the other hand, Marxist feminism argues that women are oppressed because they essentially depend of their husband for their economic wellbeing. For the Marxist improving women's economic empowerment can go a long way in addressing the challenge.In the case of this study, it follows therefore that the Human capital and feminist theories are used to examine the profile of different business owners and analyse their contribution to business growth or lack of it.

\section{Factors Affecting the Growth of Small Businesses}

Growth in small businesses is multidimensional embracing a convergence of owner manager ambitions, intentions and competences. (Morrison et al.2003:418). The authors further identify the critical role played by internal organisation factors in influencing growth such as management of resources, infrastructure, external relationships and networks.

\section{Internal Organisational Factors}

According to Hoy (2008:153), there are scholars who question whether small businesses per se are entrepreneurial. Different scholars define entrepreneurship highlighting a number of attributes. According to Hitt, Ireland, Camp (2001), entrepreneurship is the identification and exploitation of previously unexploited 
opportunities. Entrepreneurship combines innovation and provision of new goods and individual initiative, resulting in organisational renewal (Ligthelm, 2008: 367). Entrepreneurship defined by personality trait theory as a construct made up of a set of personal characteristics in particular risk taking, creativity and ambition (Ligthelm 2008: 368).

Thus when an entrepreneur possesses the entrepreneurial characteristics they have potential to grow their business venture. Entrepreneurs recognise opportunities and then use various means to exploit or develop these opportunities, thus producing a wide range of outcomes (Rwigema, et al 2011:6). Rwigema et al 2011:7 further emphasises that entrepreneurship is about venture creation and growth, where the entrepreneur examines ideas, develops opportunity and handles the process of setting up an enterprise but once the enterprise is created a different set of skills for managing the enterprise are required. These include skills such as planning, organising, leading, controlling, human resource management and other administrative issues. Franks (2008:72) further emphasises the point that entrepreneurship embraces only those businesses that show growth and development.

The bulk of small businesses can be typified as survivalist with limited dynamism and hence little entrepreneurial spirit (Ligthelm 2004:73).A point echoed by Rwigema et al (2011:7) who states that in South Africa there is an overabundance of necessity entrepreneurs. Necessity entrepreneurs constitute the build of the informal economy which is also known as the second economy. The second economy is described as that section of the economy that makes its living outside formal income means (Nevin 2005:314). Nevin further purports that in South Africa it is estimated that the second economy employs $30 \%$ of the national workforce. The inability of the formal sector to accommodate new entrants is responsible for the establishment of the small (informal, survivalist) businesses often set up to escape the plight of unemployment rather than to exploit a promising business opportunity (Ligthelm 2008:367).

Brettel and Rottenberger (2013:8) conclude that not all small businesses are entrepreneurial as many are started with limited growth ambitions. Quoting Wickham (2001:24), Rwigema et al (2011:9) identifies three factors that distinguish entrepreneurial organisations and small businesses as innovation, growth potential and strategic objectives. According to Rwigema et al (2011:126) the entire entrepreneurial process unfolds because individual entrepreneurs act and are motivated to pursue opportunities. He further highlights that "entrepreneurial intentions are the result of motivation and cognition, the latter including intellect, ability and skills". Thus, the entrepreneur's demographic variables, their ability and access to opportunities can provide opportunities for growth or inhibit growth as outlined in Table lbelow:

Table 1: Factors inhibiting or supporting growth

\begin{tabular}{|c|c|c|}
\hline Growth Factor & Pro-growth factors & Inhibiting factors \\
\hline Intention & $\begin{array}{l}\text { Demographic Variables } \\
\text { - } \quad \text { Personal Characteristics } \\
\text { - } \quad \text { Values and beliefs } \\
\text { - } \quad \text { Perceptions of own abilities }\end{array}$ & $\begin{array}{l}\text { Demographic Variables } \\
\text { - } \quad \text { Lack of ambition and vision } \\
\text { - } \quad \text { Quality of life style } \\
\text { - } \quad \text { Protectionism, mature position in life cycle }\end{array}$ \\
\hline Ability & $\begin{array}{l}\text { Education and competencies } \\
\text { - Knowledge of different fields of } \\
\text { business } \\
\text { - } \quad \begin{array}{l}\text { Perception of owner manager } \\
\text { Pro-active learning through social, } \\
\text { informal networks }\end{array}\end{array}$ & $\begin{array}{l}\text { Education and competencies } \\
\text { - } \quad \text { Constrained managerial competencies } \\
\text { - } \quad \text { Narrow skills base } \\
\text { - Organisation structure results in lack of time } \\
\text { and resources }\end{array}$ \\
\hline Opportunity & $\begin{array}{l}\text { - } \quad \begin{array}{l}\text { Ability to identify opportunities and } \\
\text { resources to support growth }\end{array} \\
\end{array}$ & $\begin{array}{l}\text { - Lack of knowledge of local industry and } \\
\text { markets }\end{array}$ \\
\hline
\end{tabular}

Adapted from Bridge O’Nell and Burke and Jarrat 2000

\section{External environmental factors and business growth}

Small businesses are affected by a number of factors in the external environment. The external environment presents both opportunities and threats for business expansion. Rwigema et al (2011:101) identified the external environment to include economic, social, cultural, demographic, environmental, political, legal, technological and competitive trends and events that could significantly benefit or harm a business in future. According to Brettel and Rottenberger (2013:471) to be successful entrepreneurs need to have the ability to identify and pursue opportunities by adapting to the dynamic environment, critical factors being rapid technological evolution, globalisation and increasingly sophisticated competitors.

\section{The Role of Human Capital in Influencing Business Growth}

Rwigema et al (2011:41) argues that micro entrepreneurs or survivalists' entrepreneurial abilities are restricted by their scarcity of skills, business knowledge and resources. Human factors that are considered to promote growth include the owner manager's desire and confidence to achieve, overcome challenges in order to realise opportunities whilst human factors inhibiting growth include lack of desire to confront and change 
factors affecting growth at personal, business and the external environment levels (Morrison et al 2003:419). The intention of the owner manager and the way in which they interpret their economic and social worlds play a pivotal role in the growth orientation of small businesses (Morrison et al 2003:419). The human factor of the owner manager according to Morrison et al is considered to be a key factor influencing business growth. Quoting Aldrich and Auster 1986, Brettel et al; 2013: 471 highlights that small businesses are affected by a liability of ownership that results from the dominant position of owner managers which further leads to dependence on the owner specific capabilities and knowledge.

\section{Contribution of business support services in the growth of small businesses.}

According to Nevin (2005:314) development of small and medium enterprises and cooperatives is one of the strategies for growing the second economy. The government of South Africa through various small enterprise development arms such as the Department of Trade and Industry, SMME policy and the Small Enterprise Development Foundationhas come up with a number of initiatives, which promote the development and growth of the small business sector (Rwigema et al 2011:236). According to Monkama (2003:4), deficiencies of the support programmes include gaps between business needs and types of services offered and the fact that some of the programmes do not develop an entrepreneurial culture. Furthermore, coordination of initiatives limits their effectiveness whilst some of the initiatives narrowly focus their range services. For instance, business development support provided by Hand in Hand is biased towards business management training. This research seeks to investigate factors that inhibit growth among informal women entrepreneurs in order to inform business development services that address the needs of small businesses.

\section{Research Design and Methodology}

This section of the study examines the overall research design, methodology, sampling and analysis of data as adopted for this study. A research design outlines theprocessof data collection, analysis, interpretation and presentation of results(Denzin \& Lincoln 2010:10). There are three major research designs: quantitative, qualitative and mixed methods designs. The study adopted the mixed methods research design and utilised a case study as the design genre. The beauty of using a mixed methods design was evident in its ability to overcome the limitations of one design, qualitative or quantitative (Nieuwenhuis, 2016). A case study was able to offer a detailed analysis of the women's activities in the organisation (Yin, 2009).

\section{Population and Sampling}

A research population is the full group of potential participants to whom the researcher wants to generalise the findings of the study (Saunders, Lewis \& Thornhill 2009). The population for the study included all the women trained in Diepsloot by Hand in Hand. According to the database of trained women, a total of 210 women have been trained inthe years 2013 and 2014. Sampling is the process used to select a fractional part of the whole relevant group or population (Saunders et al. 2009:213). There are two broad sampling approaches: probability and non-probability sampling. The former describes sampling that follows a random procedure while the latter is basically purposive or non-random (Saunders et al, 2009:213). For this study the sampling strategy chosen was purposive, which Guarte and Barrios (2006:277) describe as a random selection of sampling units within segments of the population with most information on the characteristic of interest. As part of the further specification of the research design it was requiredof the researcher to understand and consider the unique characteristics of specific research subjects and the settings in which they are located (Devers \&Frankel, 2000:263).Purposive sampling strategies are designed to enhance understandingsof selected individuals or groups' experience(s) or for developing theories and concepts andthis was accomplished through selection of individuals that provided the greatest insights to the research questions(Devers \& Frankel, 2000:263). A total of 20 women entrepreneurs werepurposively selected from trained women entrepreneurs. The trained women were divided into key sectors covered by the programme which included manufacturing, retail and agriculture. In each sector women who had shown sign of business growth in revenue and employment were identified. The sample included women with primary level education, Matric level and tertiary level of education. Of interest were women with low levels of education who have grown their small businesses in employment, access to diverse markets and revenue growth.

\section{Data Collection}

Data collection methods in the mixed methods research design are flexible and sensitive to the social context in which the data are produced as opposed to structured processes of quantitative or qualitative methodologies(Nieuwenhuis, 2016). For this study focus group discussions and open-ended questionnaires were used to collect data. A focus group discussionin this study was anin-depth discussion inwhich a small number of people (usually 8-12) fromthe target population, under the guidance of a facilitator(moderator) discuss topics of importance fora particular study (Fayisetani, 2010). The role of the moderator was to use the guidelines to 
stimulate free discussionamong the participants on the subject of inquiry (Fayisetani, 2010). According to Khan et al. (2010), an informal, supportive group ofpeople with similar backgrounds can often putpeople at ease and encourage them to express theirviews freely and frankly. In this view the focus group discussions were complemented with open ended questionnaires which the women respondents completed following a selfadministered questionnaire administration process at the organization. The respondents for the questionnaires were the women entrepreneurs and the same participants constituted the key informants for the focus group discussion sessions. The latter data collection process constituted face to face discussion sessions with the participants at their place of work at times when they were either on break or lunch time to prevent disrupting the smooth flow of their occupational roles. The focus group discussions were facilitated through an interview guide who contained open ended questions that guided the exploration of key issues affecting women owned business entrepreneurship.

\section{Data Analysis}

Data analysis, which describes a process of transforming data into research results (Le Compte 2009) involved interpreting, coding and clustering the data into what Nieuwenhuis (2016) calls super ordinate themes, that is, into succinct statements that describe, explain or predict what the respondents and participants said in the questionnaires or focus group discussions. Given the multiplicity of approaches to data analysis, for this study the analysis itself followed insights from Miles and Huberman (2002) who assert that data analysis should be conceived in terms of data reduction, presentation and inference drawing. The data reduction process for this study involvedidentifying patterns of commonalities and differences which culminated in the formulation as well as conclusion drawing. Essentially this meant that the data analysis for this study followed the thematic approach through and through. The emerging themes formed the basis for the discussion of the findings for this study.

\section{Ethical Considerations}

According to Babbie (2010:469) research ethics refers to conforming to the standardised conduct of a given profession. He further emphasises that when human behaviour is researched, ethical issues are always involved looking at how the researcher deals with ethical issues. Given that the study on factors influencing the growth of small businesses is primarily focused on human behaviour, it followed that ethical principles needed to be borne in mind (Mather, 2005). The study accessed the Hand in Hand database of entrepreneurs trained in Diepsloot who were then sampled purposively. Among the ethical principles borne in mind by the researchers in this study were ethical clearance letters introducing and authorizing the researchers to the women entrepreneurs. The participants were also informed of the purpose of the study and how the study would benefit women's small businesses developments. They were informed of the need to participate voluntarily and the option to pull out at any time should they deemed it so (Maxfield \& Babbie, 2008). Fortunately none withdrew prematurely. A letter signed by the Hand in Hand Chief Executive Officer was circulated for this purpose. The letter had a consent form that was signed by each participant prior to participating in the study. In order to ensure anonymity of respondents and participants were not required to put names on the questionnaires. Participants were informed to feel free not to answer any questions they felt uncomfortable with or they thought were sensitive for their comfort. All accessed and collected information on the participants were protected and never shared with any third parties.

\section{Results And Discussion}

The results of the focus group discussion sessions held with the 20 women entrepreneurs and their questionnaire responses are presented in the subsequent sections. The discussion of the findings also explores the similarities with the secondary data reviewed to establish where the women's views resonate with the reviewed literature. The following themes informed the discussion of the findings.

\section{External Business Environmental Factors Affecting Growth Of Women Owned Businesses}

The literature identified that external business environment has an effect on opportunities for business growth. The women entrepreneurs were asked to identify the key challenges in their external business environment that affects their ability to grow the businesses. Discussions revealed that their potential to grow their businesses is limited by a number of challenges they face such as the regulatory environment, limited access to finance, availability of secure and affordable working pace and lack of access to adequately packaged business development services among others. On environmental factors that have a positive bearing on the business, top five included access to business premises,conducive investment climate, access to business services, conducive business climate and access to financial services. 


\section{The regulatory environment}

Responding to the question of how the regulatory environment affected the growth of their businesses, entrepreneurs expressed the view that they do not have adequate support to understand the regulatory environment and how to comply with its requirements. This includes issues of business registration, taxation, labour laws and by-laws that affect their day-to-day business operations. Some (50\%) of the entrepreneurs indicated that they are not sure what benefits they will get by registering their businesses. At the same time some of the entrepreneurs did not want to register as tax payers for fear of being asked to pay a lot of money by tax authorities. Some entrepreneurs in the interviews highlighted that lack of compliance with regulatory framework has left them vulnerable as it is difficult for them to enforce contracts resulting in their clients defaulting on payment obligations.

\section{Limited access to finance}

The interviewed entrepreneurs financed their business start-up from own savings or soft loans from family, they however realise the need to access loans and other investments from external sources for their businesses to grow. Entrepreneurs highlighted several challenges they face in their attempts to access requisite financial services. Top five challenges mentioned include lack of collateral affordability of funds, lack of credit history, poor credit history and size of loan required and not being able to raise the required contribution, lack of business registration and not having a business plan. As a result of lack of access to formal sources of finance, women entrepreneurs relied on informal sources of finance, which have very high interest rates and repayment affects the cash flow of the business. Women entrepreneurs highlighted some specific enterprises that had closed due to sourcing funds from informal sources of business financing. Women indicated that their businesses needed financing for purchase of equipment, inputs and acquisition of appropriate business premises.

\section{Unavailability of business premises}

In response to question 2 in the focus group discussion guide which required that the women entrepreneurs identify some of the limiting factors of business growth, 7 entrepreneurs (35\% of the sample) involved in manufacturing activities felt that their business premises were limiting business growth. The major challenges identified included adequacy of the area space to accommodate the equipment, security of the place as some equipment are stolen, access to electricity and clean water.

\section{Nternal Business Environmental Factors Inhibiting Growth Of Women Owned Businesses}

The fundamental challenge identified by interviewed entrepreneurs is a lack of understanding of market dynamics and the industry as a whole. This according to entrepreneurs has given rise to competition from foreign owned retail shops who are studying the weaknesses of the local businesses and designing retail systems that meets the needs of the target market such as appropriately packaged goods, opening hours, customer service and quality management. Entrepreneurs feel that to grow their business and stay ahead of competition, their businesses need to invest in researching the market, understand the trends and plan for business growth. In addition, entrepreneurs have realised that there is an increasing number of bigger formal businesses being established in their communities, a development that will reduce their market share. Women entrepreneurs who participated in the study felt that internally their businesses were negatively affected by customer buying power and seasonality of their sources of income. According to the women, customers do not have buying power in the first 15 days of the month and also beginning of the year. The viability of some business activities especially catering depended on the festive activities in the community.Internal organisation factors are critical in influencing growth of businesses. The internal organisations incorporate the ability of the entrepreneur to manage resources, infrastructure, external relationships and networks.(Morriron et al 2003:418).South African Entrepreneurs in low income communities such as Diepsloot are in the main necessity entrepreneurs with low expectations of growth and job creation. The bulk of small businesses can be typified as survivalist with limited dynamism and hence little entrepreneurial spirit (Ligthelm 2004:73, Rwigema et al (2011:7). The businesses are set up for livelihood purposes and not to pursue a business opportunity which then limits growth. Interviewed entrepreneurs confirmed that when they set up their businesses, they were influenced by what other businesses were doing other than looking at business opportunities available.

On the question of what innovations their business had introduced in the past year, $90 \%$ of the respondent entrepreneurs indicated that they had not done much in adopting innovative approaches or introducing new technologies. This raises questions of the entrepreneurship qualities of the entrepreneurs interviewed. The definition of an entrepreneur according to Ligthelm (2008:367) combines innovation and provision of new goods and individual initiative, resulting in organisational renewal whilst entrepreneurship defined by personality trait theory is viewed as a construct made up of a set of personal characteristics in particular risk taking, creativity and ambition. 


\section{The Influence Of Entrepreneurial Human Capitalon Business Expansion}

Growth factors identified in literature to have an influence on business growth were explored through interviews with women entrepreneurs. The interview process sought to understand how women entrepreneurs were perceiving growth and planning to grow their businesses. The following sections explore the major variables of human capital with influence on growth. Growth in small businesses is multidimensional embracing a convergence of owner manager ambitions, intentions and competences (Morrison et al 2003:418).

\section{Entrepreneurial intention}

In discussing whether or not women entrepreneurs were intending to grow (question 4), participating entrepreneurs indicated that they had no plans for growing their businesses. The entrepreneurs were hoping their businesses will grow to be a big business. Literature identifies a number of demographic variables as discussed in chapter 2 to have an influence on business growth. Personal characteristics, values and beliefs as well as own abilities are considered to have an influence on growth. Women with at least tertiary level education, with exposure to a wide range of businesses through networks had an ambition to grow their businesses beyond what it is today. Such women have a belief that they too can grow the business, and target different markets. It was interesting that women who were less exposed to businesses outside their environment, could not articulate an ambition and vision for growth. Virtually all the 20 women interviewed did not have a clear vision for growing their businesses. Older women appeared to be interested in maintaining their businesses instead of growing the business. Women entrepreneurs were of the opinion that growth of their business would be achieved if they get support from government and other institutions. Women in the interviews attributed growth that has occurred to incidental opportunities where developments in the community such as a school being built or a competitor shop closing as triggers to business growth.These findings lent credence to the literature which identified perception of growth for the entrepreneur to be a key attribute to growing a business. Interviewed entrepreneurs also felt that for the business to grow the entrepreneur should be committed to the business and its growth.

\section{The ability of the entrepreneur to initiate and sustain growth}

Women entrepreneurs identified a number of training services that they needed for their businesses to grow. This included the aspects shown in table 1below.

\section{Knoweldge markets and opportunities}

\section{Business management skills}

Financial skills
- Information on markets and tenders

- knolwedge of industry and Information on tenders

- Mentoring by experienced business persons

- Training in customer care and planning for business growth

- Financial literacy

- Making sound financial decisions and Financial planning

More than $75 \%$ of women entrepreneurs interviewed indicated that there is hardly any information on the available markets. What makes it interesting is that women entrepreneurs in the main are not part of associations or business networks where such information in disseminated. Interviewed women were not aware of any business associations where they could contribute to discussions on entrepreneurship, share experiences and access information which better equips their business management decisions. Asked about their vision for growth, most entrepreneurs $(80 \%)$ indicated that they have not developed any vision for their businesses. Discussions further revealed that women entrepreneurs interviewed were not aware of the need of a vision and they did not know how to develop a strategic direction for their businesses. As a result, changes in the business were haphazard and often uncoordinated. Women entrepreneurs applied observation and experimentation in the running of their businesses with minimum forecasting.

The issues of pro-active learning through social and informal networks as identified in chapter two was a critical contributor to business growth. Not only should an entrepreneur participate in social networks, but they also need to have a fair knowledge of different fields of business. Interviewed women entrepreneurs did mention the need to network with other business women. However, the challenge they faced was that most of the women entrepreneurs in their community were lowly educated, will limited interaction with the wider industry. The lack 
of exposure limited the quality of information that could be shared in the local interactions with other business persons.Access to managerial competencies, interviewed women entrepreneurs we the owner manager in their businesses. With low levels of education, this implies that the managerial competencies are constrained in the business. On the other hand, being a sole proprietor negatively affects the business's ability to access resources and adequate skills. According to women entrepreneurs, even in instances where the business needs specialised skills of baking, selling, marketing it is difficult to find the skills in the community and the few available skilled people are very expensive for the business to engage.

\section{Personal development}

Women entrepreneurs in the interviews recognised the need to continue learning. Of particular interest was the issue ofknowing how to identify opportunities, research on them and develop a viable business with potential for growth from those opportunities.Discussions with women entrepreneurs established the importance of the ability of women entrepreneurs to keep abreast of changes in the business environment. $65 \%$ of women interviewed considered doing a SWOT analysis (strengths, weaknesses, opportunities and threats analysis) to be critical as a foundation for developing a clear growth strategy. This needed to be complemented by industry analysis to appreciate opportunities and challenges of that specific industry. As discussed in the last section, access to appropriately packaged information was considered to inhibit the growth of small businesses run by women. Table 2 below summarises the interventions women entrepreneurs interviewed considered to be important for business growth.

Table 2: Important interventions for business growth

\begin{tabular}{|l|l|l|l|}
\hline Important interventions for business growth & $\mathbf{\%}$ & Important interventions for business growth & \% \\
\hline Mentorship/ Coaching/ Training & $85 \%$ & Business management & $100 \%$ \\
\hline Technical skills & $65 \%$ & Business expansion & $55 \%$ \\
\hline Develop business plans & $90 \%$ & Training staff in specific industry skills & $60 \%$ \\
\hline Development of growth plans based on identified & $60 \%$ & Training on customer care & $50 \%$ \\
\hline Opportunities for growth & $65 \%$ & Social activities - (sponsorships) & $45 \%$ \\
\hline Financial management skills & $75 \%$ & Information on markets & $80 \%$ \\
\hline
\end{tabular}

As is apparent from Table 2 above that the majority of women entrepreneurs interviewed considers interventions such as training in business management skills (100\%), development of business plans (90\%), mentoring/coaching/training (85\%) and access to information of markets $(85 \%)$ to be key in facilitating business growth.

\section{Perceived Challenges Limiting Growth Of Women Owned Businesses}

The majority (75\%) of women entrepreneurs interviewed felt that the low financial literacy rate was limiting their ability to manage their finances and utilise a variety of financial services that can benefit their businesses. The women were also of the opinion that limited education affected their ability to innovate on new products and services. In addition, young people who were coming with innovations often lacked guidance on how to develop the business concept inline with the innovation. This point is echoed by Duane et al (2003:966) who advocates that small companies are relatively skilled in identifying entrepreneurial opportunities but less effective in developing and sustaining the competitive advantage causing other people to seize the opportunities and develop them into big businesses. A case in point is the concept of a Spaza shop which has now been taken up by business persons from outside the communities who have built big business networks out of the concept.Other key issues emanating from the interviews held affecting business growth related to weak business management skills. Entrepreneurs felt in most cases they fail to differentiate between sales and profit. Entrepreneurs also shared examples of how their fellow business people who were fortunate to receive loans diverted these funds resulting in defaulting on the loan repayment. Entrepreneurs also highlighted that lack of commitment was limiting growth.Other business management related challenges identified included record keeping to be able to understand the performance of the business, its products and customer buying patterns. Entrepreneurs interviewed also identified the entrepreneurship culture as a key element towards the development of growth oriented entrepreneurs. Other challenges highlighted included:

- lack of clear and concrete business ideas

- Lack of entrepreneurial and creativity spirit

- Lack of commitment from the entrepreneurs

- Unwillingness to pay for services as people think it's a government providing services

- Expectation for loans and grants after attending training

The above analysis highlights the diversity of challenges faced by the women entrepreneurs interviewed most of which emanate from internal capacity or entrepreneur attitude related challenges and while 
others are externally induced. Appropriately couched interventions aimed at addressing these limiting factors should therefore be designed.

\section{Role Of Enterprise Support Programmes In Influencing Women Owned Businesses}

The development of an entrepreneurship culture, business management and entrepreneurial skills development hinge a lot on the availability of appropriately packaged and accessible business development and support services. The major challenge that literature identifies in relation to provision of support services for small businesses relates to appropriateness, efficiency and accessibility.Most entrepreneurs interviewed (85\%) felt that business support services were not sufficiently available to support business growth. The entrepreneurs highlighted that most of the training and support services are provided by NGO donor supported institutions that only offer adhoc services and thus do not cater to the holisticbusiness development needs of entrepreneurs. The women entrepreneurs interviewed further highlighted the following challenges when accessing business support services.

Table 3: Challenges faced when accessing business support services

- Lack of dedicated centres for teaching entrepreneurship and supporting business growth

- Unavailability of appropriately packaged financing packages that are accessible and appropriately packaged for small businesses

- Access to technical skills to support existing businesses in the community

- Poor labour ethics (money oriented not achievement oriented)

- Lack of access to specialised technical expertise in line of business

- Lack of a One Stop Business based in the community

- Cost of accessing the services

The list of challenges faced by entrepreneurs summarised in Table 4 shows that the challenges are predominantly operating environment driven. They are factors that government and other development oriented stakeholders could put measures in place to mitigate their negative impact on women entrepreneurs, for example, the issue of dedicated centres which provide entrepreneurship development training at subsidised cost.Five mainbusiness services that entrepreneurs indicated they require and have difficulty in accessing include access to information on tender opportunities, mentorship, coaching, training and access to technical skills and access to appropriately packed financial products. Other areas of support include skills to develop bankable business plans with opportunities for growth. Entrepreneurs interviewed were also concerned that there are no follow-up services to visit their enterprises and assess areas of improvement by the service providers. In addition, lack of standardization has meant that they attend similar training from different service providers. Furthermore, entrepreneurs felt that access to business and market information was not adequate, establishment of an information centre within the community would be of great benefit. An information portal would allow entrepreneurs to access a wide range of information on industry specific issues, market issues and opportunities for business growth.The foregoing points to the need for concerted efforts by government, the private sector and other development institutions to take systematic steps to create institutions and other infrastructure support targeted at facilitating access to business support services by women entrepreneurs.

\section{Conclusion}

In view of these findings, this studyconcludes that the contribution of internal and external business environmental factors in facilitating and inhibiting the growth of women owned businesses cannot be underestimated. Further to this, the influence of entrepreneurial human capital development and sensitivity to gender equality in entrepreneurship can also not be taken lightly in business development initiatives. The study also concluded that women entrepreneurs basically lack basic information on their industry, the economy and their community activities. Whilst women entrepreneurs identified the external environmental factors as affecting their businesses ventures, they also recognised the need for more exposure to opportunities and risks that are existent in the sector. Failure to interpret the environment by the entrepreneur affects the business's strategy and choices it makes in response to the risks and opportunities from the environment. 


\section{Recommendations}

The conclusions stated in the preceding section lead the researchers to make the following recommendations: when doing business analysis, women certainly need to assess the potential impact of all the elements on the growth and profitability of the business. This recommendation resonates with the views of Nieman, Hough and Nieuwenhuzen (2008) who maintain that any business support initiatives need to recognise the need to introduce environmental scanning as part of their business training curriculum. Most importantly, entrepreneurs need to be introduced to the environmental scanning frameworks. Other recommendations are that there is need for information sharing portals to be introduced in the business community so that the women can compare notes and share on the aspects. Mentorship and incubator programmes also need to be set up in the communities where women owned businesses are established as this will go a long way towards improving their internal business environments. It is also important that business support services aimed at women entrepreneurship development incorporate gender and entrepreneurship elements and an emphasis on human capital development will go a long way in improving the entrepreneurial qualities essential for business growth. Furthermore, women entrepreneurs need comprehensive training support that includes follow-up and mentorship to deal with business challenges they face. Provision of appropriately packaged business finance schemes and services are essential to facilitate growth and therefore these should be stepped up in practice.

\section{References}

[1] Babbie, E. (2010).The Practice of Social Research $9^{\text {th }}$ edition Australia Wads Worth

[2] Bryman, A. \& Bell, E. (2007). Business Research Methods, second edition, Oxford University press

[3] Brettel, M. Rottenberger, J. D. (2013) Examining the Link between Entrepreneurial Orientation and Learning Process in Small and Medium-sized Enterprises. Journal of Small Business Management $471-490$

[4] Cambra-Fierro J. and Wilson A. (2011). Qualitative data analysis software: will it ever become mainstream? Evidence from Spain, International Journal of Market Research Volume 53 Issue 1

[5] Calas M., Smircich L \&Bourne K. A. (2009). Extending the Boundaries: Reframing "Entrepreneurship as social change" -through the Feminist Perspectives volume 34 No.3 552-569

[6] Duane, V. (2003). Growth in Gender equity in the business world. Pretoria: Van Schaik

[7] Fayisetani, T. (2010). Focus group discussions as a data collection method: Insight into qualitative data collection tools. Paper presented at the ICET World Assembly, Ghana July 22-25 2010

[8] Frank, H. (2008). Organisational Learning at the Marketing/Entrepreneurship Interface. Journal of Small Business Management 152 $-158$

[9] Gauteng Department of Economic Development (2014), Revitalisation of the Township Economy Strategy. Government of South Africa

[10] Hitchinson, F.\& Mann, (2004) Entrepreneurial Perceptions ad intentions: The Role of Gender and Culture. Baylor University

[11] Hoy, W. (2008). How South Africa can Boost Support to Small Businesses: Lessons from Brazil \& India International Journal of Education Sciences 8 (3):14-19

[12] Le Compte, B. (2009). Procedures for data analysis in the mixed methods research design. New York: Sage

[13] Ligthelm, A.A. (2008). A targeted Approach to Informal Business Development: The Entrepreneurial Route. Development South Africa, 25(4):14-21

[14] Maxfield, M.G. \&Babbie E. (2008) Research Methods: Quantitative and Qualitative Approaches Boston: Allyn and Bacon

[15] Mather, C. (2005), The Growth Challenges of Small and Medium Enterprises (SMEs) in South Africa's Food Processing Complex. Development Southern Africa Vol.22. No. 5

[16] Monkana, S. (2003). Business entrepreneurial skills in the informal sector. Journal of Social Sciences 35 (2): $311-332$

[17] Miles, MB.\& Huberman, MA. (2002). Qualitative data analysis: An Expanded source book, New York: Sage

[18] Morrison, A., Breen, J.\&Ali, S. (2003). Small Business Growth: Intention, Ability and Opportunity. Journal of Small Business Management pp $417-425$

[19] Nevin, T. (2005). Formalising the Informal. African Business Issue 314

[20] Nieman, G., Hough, J., Nieuwenhuzen, C., (2008). Entrepreneurship: A South African Perspective. Van Schaik Publishers.

[21] Nieuwenhuis, J. (2016). Qualitative data analysis. In K Maree (ed) First Steps in Research. Pretoria: Van Schaik (pp 74-82)

[22] Peterson, S. (2004). Feminist Theories Within, Invisible To, and Beyond IR, University of Arizona, Brown Journal World Affairs Volume X, Issue 2

[23] Saunders, M., Lewis, P. \& Thornhill, A. (2012). Research Methods for Business Students. $6^{\text {th }}$ Edition. Harlow, England: Financial Times, Prentice Hall.

[24] Rwigema, H.; Urban, B.; Venter, R. (2011). Entrepreneurship Theory in Practice. Oxford University Press South Africa

[25] United Nations Women (2016) Transforming Economies. New York: Donnelly Company

[26] Wasserman, N. (2012). The Founder's Dilemmas. Princeton University Press

[27] World Bank (2014). Economics of South African Townships. International Bank for Reconstruction and Development. The World Bank Group Washington 